\title{
PREPARATION AND CHARACTERIZATION OF CALCIUM OXIDE FROM CRAB SHELLS (Portunus pelagicus) ANDITS APPLICATION IN BIODIESEL SYNTHESIS OF WASTE COOKING OIL, PALM AND COCONUT OIL
}

\author{
Minaria ${ }^{1, *}$, Risfidian $_{\text {Mohadi }}{ }^{1}$ \\ ${ }^{1}$ Department of Chemistry, Faculty of Mathematic and Natural Sciences, Sriwijay a University \\ ${ }^{*}$ Corresponding authrore-mail :minariaar@gmail.com
}

\begin{abstract}
Preparation of calcium oxide from Portunus pelagicus through thermal decomposition for 3 hours at various temperature $700^{\circ} \mathrm{C}$, $800^{\circ} \mathrm{C}, 900^{\circ} \mathrm{C}, 1000^{\circ} \mathrm{C}$, and $1100^{\circ} \mathrm{C}$. The calcium oxidefrom decomposition was carried out and characterized by X-Ray Diffractometer (XRD), FT-IR spectrophotometer and SEM-EDX analyses. The result of XRD show decomposition Portunuspelagicus at $1000^{\circ} \mathrm{C}$ have diffraction pattern agree with the $\mathrm{CaO}$ diffraction standard with $2 \theta$ value $32.4^{\circ}, 37.5^{\circ}, 64.3^{\circ}$, and $67,5^{\circ}$. The FT-IR spectrum show vibration of $\mathrm{CaO}$ at wavenumber $354.9 \mathrm{~cm}^{-1}$. SEM-EDX data indicated the surface morphology calcium oxide of Portunuspelagicus more homogen than Portunuspelagicus before decomposition. The decomposition of $\mathrm{CaO}$ at $1000^{\circ} \mathrm{C}$ was applied in the syntesis of biodiesel from waste cooking oil, palm oil, and coconut oil. The biodiesel products have density $0.8621,0.8725$, and $0.8688 \mathrm{~g} / \mathrm{cm}^{3}$. Viscosity are 5.27, 3.71, and $2.45 \mathrm{~mm}^{2} / \mathrm{s}(\mathrm{cst})$. Acid values respectively are $0.3069,0.2423 \mathrm{and} 0.2100 \mathrm{mg} / \mathrm{KOH}$ and Iodine numbers 39.48, 36.12 and $9.24 \mathrm{~g} \mathrm{I} / 100 \mathrm{~g}$. All characteristic of biodiesel from waste cooking oil, palm oil, and coconut oil are agree with SNI standard. The best biodiesel product derived from coconut oil is agree to the parameter value of biodiesel standard.
\end{abstract}

Keywords: biodiesel. Portunuspelagicus. calcium oxide. catalyst.

\section{INTRODUCTION}

Biodiesel is an alternative of diesel fuel, made from biodegradable sources such as vegetable oils and animal fats that are biodegradable, non-toxic, have low filtration profiles and environmentally friendly (Ma et al., 1999). Biodiesel is an alternative fuel used as a renewable energy source and is also a sustainable fuel (Boey et al. 2009). Sources of raw materials to synthesize biodiesel include, for example, vegetable oils and animal oils, induding cooking oil.

One of the ways to create Biodiesel is through using triglyceride reaction with alcohol using an alkaline catalyst. (Tamba, 2012). The basic catalyst used in the reaction may be a homogeneous or heterogeneous catalyst. Homogeny catalysts such as $\mathrm{NaOH}$ and $\mathrm{KOH}$ are commonly used for transesterification reactions. However, heterogeneous catalys ts are more interesting to studybecause the separation between the product and the catalyst is easy, and the catalyst can be reused so as to reduce production costs (Lesbani et al., 2013). In addition, calcium oxide can be produced from bone fish and cow bone, as reported (Ceria, 2013) from the research obtained calcium oxide catalyst with the best decomposition results is at temperatures $1000^{\circ} \mathrm{C}$ and $1100{ }^{\circ} \mathrm{C}$. Then (Amriana, 2014) makes $\mathrm{CaO}$ catalyst from duck eggshell and produces the best decomposition of calcium oxide at a temperature of $900^{\circ} \mathrm{C}$. The resulting catalyst (Amriana, 2014) has been applied in the synthesis of biodiesel from cooking oil through transesterification reaction and yields biodiesel with a yield of $53.57 \%$ ( $\%$ v / v). Sueb (2014) produced a calcium oxide catalyst

\section{Article History}

Received: 21 July 2016

Accepted: 30 Semptember 2016 from quail egg shell with a decomposition temperature of $900^{\circ}$ $\mathrm{C}$, after application in biodiesel synthesis from cooking oil produced a yield of $55.71 \%(\% \mathrm{v} / \mathrm{v})$. Based on the research that has been described above, in this study, calcium oxide catalyst from another source, namely the shell crab (Portunus pelagicus). The crab shell was prepared and decomposed with various temperature variations. Calcium oxide catalyst obtained was applied in the synthesis of biodiesel from used cooking oil, palm oil and coconut oil.

\section{EXPERIMENTAL SECTION}

\section{Materials and Instrumentation}

Pycnometer, diffractometer XRD, spectrophotometer FTIR Shimadzu, and SEM -EDX JED-2300 Analysis Station Brand JEOL were used for characterization of material in this research. Materials used in the study is crab shells, cooking oil, palm oil and coconut oil, methanol pa, ethanol pa, fenolptalin indicators, anhydrous sodium sulphate, potassium hydroxide, oxalic acid, iodine bromide, distilled water, sodium thiosulfate, phosphoric adid, carbon tetrachloride, reagents wijs, and starch .

\section{Preliminary Sampling and Preparation of Crab Shells}

The crab shells were taken randomly from several sampling locations in Palembang. The stored crab shell was washed and dried in an oven with a temperature of $100^{\circ} \mathrm{C}$ to remove water. Dry crab shell was crushed and sieved to pass the size of 100 meshes. A fine shell of a small size of 100 meshes is characterized by X-ray diffraction. The fine shellfish shell of the sieve is ready for the next procedure.

DOI: $10.26554 /$ sti.2016.1.1.1-7 


\section{Preparation and Characterization of Calcium Oxide from the Shell of the Crabs}

The crab shells that are sieved through a 100 mesh sieve for as much as $100 \mathrm{~g}$ were decomposed with furnace under oxygen atmospheric conditions at various temperature variations. The temperature variations used were $700,800,900,1000$ and 1100 ${ }^{\circ} \mathrm{C}$ for 3 hours. After the cold the obtained solids were stored in the desiccator for 24 hours according to Nakataniet al. 2009. Characterization was done by using X-ray diffraction to see the metal oxide structure formed. The resulting characterization results are then compared to the standard JCBI calcium oxide data which is the standard for XRD pattern data.

\section{Characterization of Oxide of Preparation Result}

The best result of the decomposition process of the crab shell is marked by XRD pattern which is suitable and dose to JCPDS standard, then the result will be analyzed with FT-IR and SEM spectrophotometer.

\section{Sampling of Waste Cooking Oil (WCO), Palm Oil and Coconut Oil}

Waste oil is taken from household waste in Indralaya. WCO obtained is deaned of impurities by means of filtration and then stored in a container. Clean cooking oil will be used in the transesterification process. While palm oil and coconut oil can be directly used.

\section{Study of Transesterification of WCO, Palm Oil and Coconut Oil with Catalytic Preparation Result into Biodiesel}

The transesterification reaction was carried out using a 500 $\mathrm{mL}$ Schlenk flask equipped with a pumpkin flap. A total of 100 $\mathrm{mL}$ of cooking oil, palm oil and coconut oil each added methanol p.a. As much as $40 \mathrm{~mL}$ followed by the addition of $\mathrm{CaO}$ catalyst of the preparation result of a crab shell of $0.2 \mathrm{~g}$. The reaction was heated at $65^{\circ} \mathrm{C}$. for 3 hours. The reaction is stopped by putting a container containing ice water. The reaction product was left overnight for several phases followed by separation by addition of $1 \mathrm{~mL}$ of $\mathrm{H}_{3} \mathrm{PO}_{4}$ for the neutralization process.

\section{Distillate Biodiesel Products}

The results of the transesterification reaction are further distilled. Warming of the product is performed by heating the mantle at a temperature of $65^{\circ} \mathrm{C}$ to separate the methanol solvent on the mixture and $100^{\circ} \mathrm{C}$ for separation by water. The product evaporates and separates the biodiesel fraction from steam to the condenser. The result of distillation is then measured for its volume qualitatively.

\section{Determination of Density of Biodiesel Product}

The density measurements were carried out in a water bath with a temperature of $25 \mathrm{oC}$. Aquadest as a standard was incorporated into a pyrometer that has been known to weigh, then weighed again. Pycnometer containing the product, was soaked in a temperature-adjusted waterbath for approximately 15 minutes. After that the pycnometer is dried off outside the water bath and weighed. The same treatment is done for aquades as a comparison. The same procedure is also carried out for the determination of density on waste cooking oil, palm oil and coconut oil.

Density $=\frac{\text { wproduct }}{\text { Vpycnometer }}$

\section{Determination of Viscosity Test of Biodiesel Product (ASTM D-445)}

The biodiesel sample is inserted into the viscometer and then inserted in the water bath. The upper line of the viscometer is arranged so that the line is $3 \mathrm{~cm}$ below the water level in the water bath, then covered with rubber and left for 1 hour. Next the lid is opened and the sample is allowed to flow. The sample flow time is recorded from the first line to the second line in seconds. If the flow time is less than 200 seconds, then the determination is repeated using a viscometer with a smaller factor. The same procedure was performed for the determination of density in cooking oil, palm oil and coconut oil. Viscosity formula:

$$
\mathrm{KV}=\mathrm{F} \times \mathrm{t}
$$

Where $: \mathrm{KV}=$ Kinematic Viscosity

$\mathrm{F}=$ Viscometer factor

$\mathrm{t}=$ Flow time of example

\section{Determination of Acid Numbers by Titration Method}

$5 \mathrm{~g}$ of biodiesel samples were weighed and then added with $10 \mathrm{~mL}$ ethanol, after stirring the sample to be boiled until boiling, after which it is stirred until completely dissolved. The resulting sample is titrated with $\mathrm{PP}$ indicator using a $\mathrm{KOH}$ titrant to produce a pink color. The same procedure is performed on cooking oil, palm oil and coconut oil prior to transesterification as a preliminary treatment.

The acid number formula:

$$
\text { Adid Numbers }=\frac{\text { mL KOH x N KOH x 56,1 }}{\text { Sample Weight }}
$$

\section{KOH Standarization}

A total of $102 \mathrm{mg}$ of oxalic acid was induded in Erlenmeyer $250 \mathrm{~mL}$ and then added with $25 \mathrm{~mL}$ of distilled water. In the mixture is added PP indicator and titrated with $\mathrm{KOH}$ which will be standardized until it was pink. Repeat for three times.

\section{Standard Test for Iod Numbers (SNI 04-7182-2006)}

Biodiesel from transesterification reaction weighed as much as $0.5 \mathrm{~g}$ and then put into Erlenmeyer. Then $10 \mathrm{~mL}$ of chloroform solution and $25 \mathrm{~mL}$ of Wijs reagent are added to the erlenmeyer, shaken until all oil is well blended and let stand in a dark room for 30 minutes. $10 \mathrm{ml}$ of $15 \% \mathrm{KI}$ solution added. The titration was carried out with $0.1 \mathrm{~N} \mathrm{Na}_{2} \mathrm{~S}_{2} \mathrm{O}_{3}$ solutions and the indicator used was starch $1 \%$, titration to a dear solution. The same procedure is also carried out for the determination of iodine quantities in cooking oil, palm oil and coconut oil.

\section{The iodine number is calculated by the formula:}

$$
\text { Iod Number }=\frac{(B-C) \mathbf{1 2 , 6 9} x \boldsymbol{N}}{W}
$$

Information : 
$\mathrm{C}=$ Volume of Sodium Tiosulfate solution spent in sample titration (ml)

$\mathrm{B}=$ Volume of Sodium Tiosulfate solution spent in blank titrations (ml)

$\mathrm{N}=$ Normalities of Sodium Tiosulfate solution

$\mathrm{W}=$ The weight of the alkyl ester sample weighed for analysis

(g)

\section{RESULTS AND DISCUSSION}

\section{Preparation of Calcium Oxide from the Shell of Crabs}

Preparation of calcium oxide from crab shell was done by decomposition process in a furnace done at variation of temperature starting from $700{ }^{\circ} \mathrm{C}, 800{ }^{\circ} \mathrm{C}, 900{ }^{\circ} \mathrm{C}, 1000{ }^{\circ} \mathrm{C}$ until $1100^{\circ} \mathrm{C}$, for 3 hours. The $\mathrm{CaO}$ was derived from $\mathrm{CaCO}_{3}$ which decomposed due to heating at high temperature, but also to remove organic compounds contained in the crab shell. Based on the result of decomposition, physical changes of crab shells powder before and after the decomposition can be seen in Figure 1.

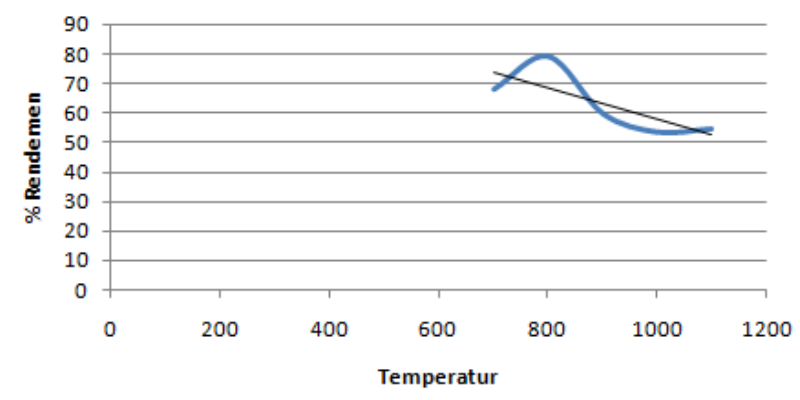

Figure 1. Percentage of Yield in Various Temperatures.

Based on Figure 1, the result of each decomposition proces s with temperature variation shows the tendency of the higher heating temperature, the weight of the solid decreases. Changes also occur in the color of crab shell powder. Shell crab powder is reddish before decomposition, then the color turns grayish at a decomposition temperature of $700^{\circ} \mathrm{C}$ and turns white by increasing the decomposition temperature. This happens because of the loss of organic compound contained in the shell, after the process of decomposition with high temperatures.

\section{Identification of Calcium Oxide Preparation Results of Crab Shell with XRD analysis}

The decomposition result of the crab shells was characterized by X-Ray Diffractometer, this measurement resulted in the diffraction pattern of calcium derived compounds such as $\mathrm{CaO}, \mathrm{Ca}(\mathrm{OH})_{2}, \mathrm{CaCO}_{3}$, as the main compound. The diffractogram pattern of the resultant decomposition of the crab shell was matched with the Joint Committe Powder Diffraction Standard (JCPDS) diffraction pattern as a comparator or standard for obtaining pure $\mathrm{CaO}$. Diffractogram of the standard $\mathrm{CaO}$ compounds are presented in Figure 2. While the diffractogram of $\mathrm{CaO}$ compounds from the crab shell with various decomposition temperatures are presented in Figure 3. Based on Figure 1 the result of decomposition of crab shells at temperatures of $700{ }^{\circ}$ and $800^{\circ} \mathrm{C}$ looks peak produced very far from JCPDS standard. Due to the decomposition of $700^{\circ} \mathrm{C}$ and $800^{\circ} \mathrm{C}$ the peaks of $\mathrm{CaCO}_{3}$ are still many even the peak with the highest intensity was the peak for $\mathrm{CaCO}_{3}$ region. While the peak for $\mathrm{CaO}$ only appears with a weak intensity. For decomposition results at temperatures of $900{ }^{\circ} \mathrm{C}$ the appearance of peaks is in the four areas of $\mathrm{CaO}$ with a value of $2 \theta$ dose to the standard although the difference is not so great but the peak intensity produced increases very much. In addition to the peaks for $\mathrm{CaO}$ that are increasingly dose to JCPDS standards at this decomposition temperature, the peaks showing the presence of $\mathrm{CaCO}_{3}$ and $\mathrm{Ca}(\mathrm{OH})_{2}$ were decreasing. Decomposition results at a temperature of $1000^{\circ} \mathrm{C}$ the appearance of the highest intensity $\mathrm{CaO}$ peak and doser to the JCPDS standard diffractogram pattern. But unlike the diffraction patterns generated at the decomposition temperature of $1100{ }^{\circ} \mathrm{C}$, although the peak areas produced at the same diffraction but the intensity are weakened, there is also a peak that states $\mathrm{CaCO}_{3}$ and $\mathrm{Ca}(\mathrm{OH})_{2}$ which at the previous temperature was no longer visible.

Based on the intensity and value of $2 \theta$ obtained on each decomposition result the higher temperature the more $\mathrm{CaCO}_{3}$ decomposes and thus more and more $\mathrm{CaO}$ is formed, at a temperature of $700{ }^{\circ} \mathrm{C}$ the appearance of two medium-intensity $\mathrm{CaO}$ peaks in the $2 \theta$ region approaching the JCPDS standard Ie at $32.1^{\circ}$ and $64.9^{\circ}$ with an intensity of 96 and 65 , this indicates the presence of decomposing $\mathrm{CaCO}_{3}$. Whereas at a decomposition temperature of $800^{\circ} \mathrm{C}$, the emerging $\mathrm{CaO}$ peaks grew, at values of $2 \theta: 32.2^{\circ}, 37.4^{\circ}, 64.8^{\circ}, 67.5^{\circ}$ with an intensity of 223 , 547, 44 and 68, This shows the more decomposed $\mathrm{CaCO}_{3}$, but it can also be seen by the decreasing of the peaks of $\mathrm{CaCO}_{3}$ that appears.

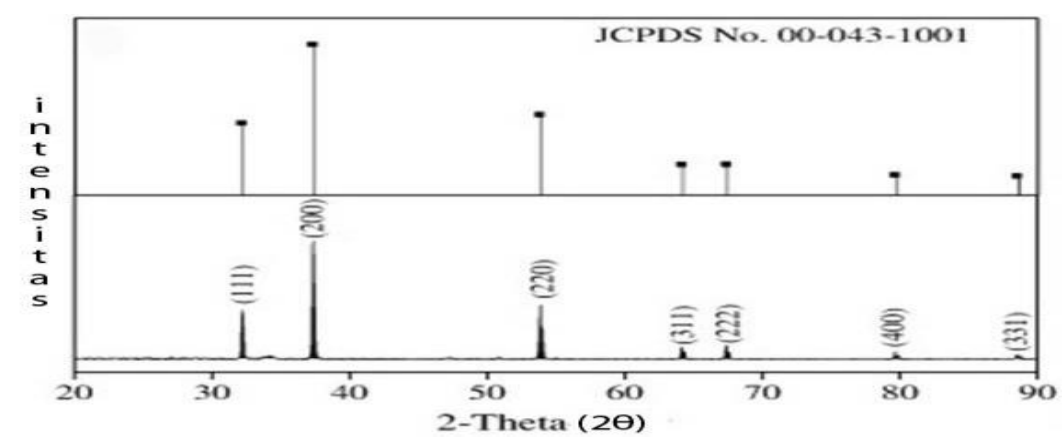

Figure 2. Diffractogram for CaO compound JCPDS Standard No. 00-043-1001 


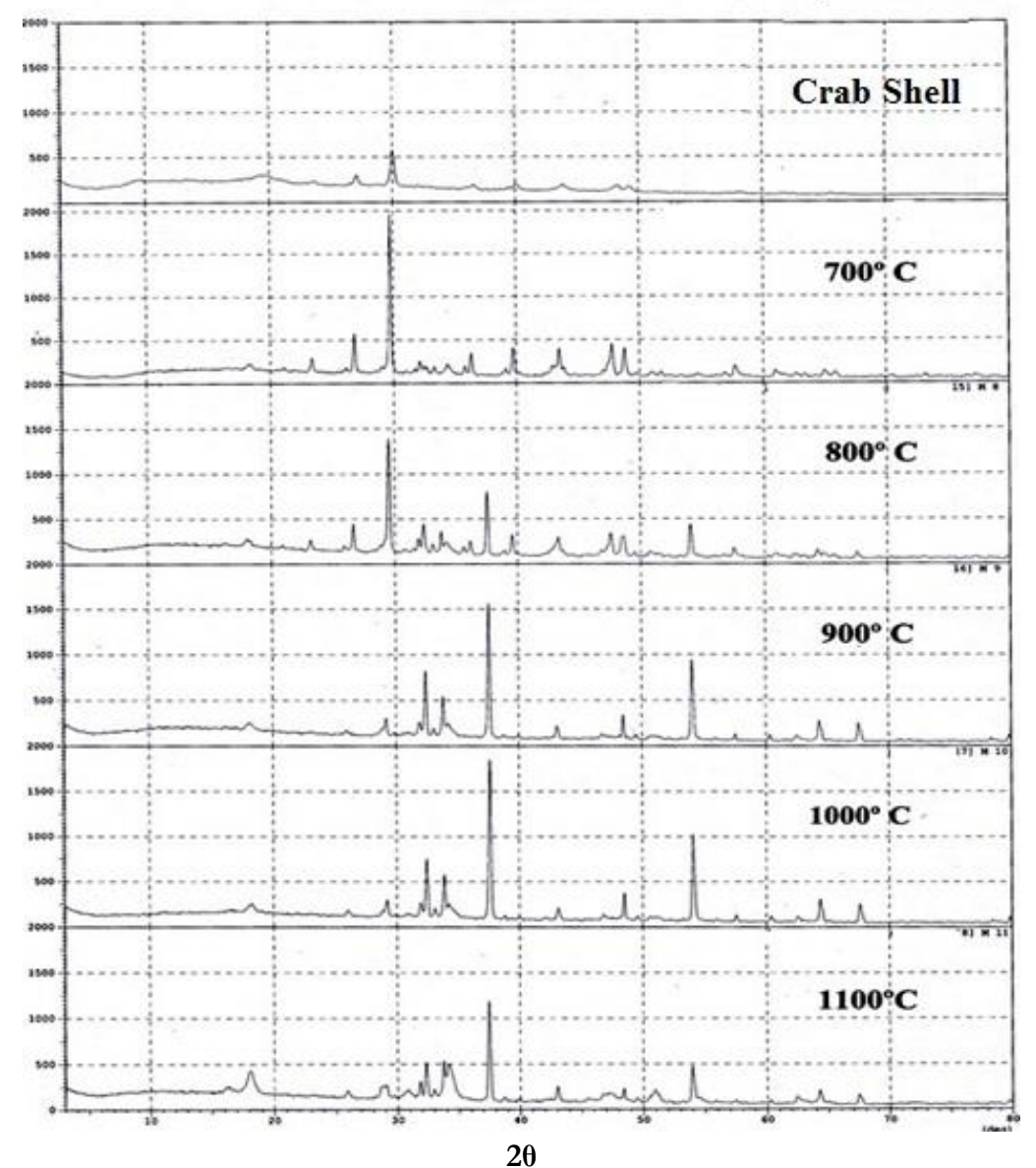

Figure 3. Diffractograms of the Crab Shells Decomposition at Various Temperatures

Decomposition results at temperatures of $900{ }^{\circ} \mathrm{C}, \mathrm{CaO}$ peaks appear increasingly dose to $\mathrm{CaO}$ standards ie at $2 \theta: 32.3^{\circ}$, $37.5^{\circ}, 64.3^{\circ}, 67.5^{\circ}$. However, these areas have similarities with the decomposition at a temperature of $1000^{\circ} \mathrm{C}$, the peak that appears at $2 \theta: 32.4^{\circ}, 37.5^{\circ}, 64.3^{\circ}, 67.5^{\circ}$ so as to determine the best between the two seen from the highest peak intensity, from the analysis results obtained the best decomposition that is at temperature $1000{ }^{\circ} \mathrm{C}$ with intensity 468, 1377, 230, 191. At decomposition temperature $1100{ }^{\circ} \mathrm{C}, \mathrm{CaO}$ peak becomes weaker that is with intensity at $276,855,122$ and 102 at $20: 32.2^{\circ}, 37.4$ ${ }^{\circ}, 64.2^{\circ}, 67.4^{\circ}$. Based on the diffraction pattern obtained and matching with the existing JCPDS standard then the solids taken with decomposition temperature $1000{ }^{\circ} \mathrm{C}$ as the best decomposition result because the peak of $\mathrm{CaO}$ on the decomposition at temperature $1000{ }^{\circ} \mathrm{C}$ the highest intensity is 1377. Further characterization is done by using spectroscopy FT-IR in crab shells of decomposition at $1000{ }^{\circ} \mathrm{C}$ and compared with standard $\mathrm{CaO}$.

The value of $2 \theta$ for $\mathrm{CaO}, \mathrm{Ca}(\mathrm{OH})_{2}, \mathrm{CaCO}_{3}$ showed the standard of JCPDS is presented in Table 1 as a comparison of the compound content in each treatment of temperature variation can be analyzed by observing in detail the diffraction at $2 \theta$ as presented in Figure 3.

The results of XRD diffraction pattern analysis of decomposition approaching $\mathrm{CaO}$ standard in crab shell were identified using FTIR spectrophotometer. Characterization by FTIR aims to identify functional groups formed on solids of the preparation. In this research, the result of decomposition of shell crab at $1000^{\circ} \mathrm{C}$ and crab shells that has not been decomposed analyzed by FTIR. The FTIR spectra of measurement results is presented in Figure 4.

Table 1. $2 \theta$ Value for $\mathrm{CaO}, \mathrm{Ca}(\mathrm{OH})_{2}, \mathrm{CaCO}_{3}$ Standard Compounds from JCPDS.

\begin{tabular}{llllll}
\hline Compound & \multicolumn{5}{c}{$2 \theta$} \\
\hline $\mathrm{CaO}$ & $34.2^{\circ}$ & $37.3^{\circ}$ & $58.3^{\circ}$ & $64.1^{\circ}$ & $67.3^{\circ}$ \\
$\mathrm{CaCO}$ & $29.4^{\circ}$ & $39.4^{\circ}$ & $43.2^{\circ}$ & $47.4^{\circ}$ & $48.5^{\circ}$ \\
$\mathrm{Ca}(\mathrm{OH})_{2}$ & $28.6^{\circ}$ & $47.1^{\circ}$ & $50.8^{\circ}$ & - & \\
\hline
\end{tabular}

Source : (Nakatani et al. 2009)

Figure 4 shows that there were functional groups in the 400$4000 \mathrm{~cm}^{-1}$ wave region. This range of wavelengths can be divided into two main regions ie in the range of the wave number 400 $1000 \mathrm{~cm}^{-1}$ as the area for the identification of inorganic compounds and the $1000-4000 \mathrm{~cm}^{-1}$ wave number range as the basis of organic compounds to facilitate the observation

The absorption of calcium oxide which is the target compound is expected to be observed in the range of 250-400 $\mathrm{cm}^{-1}$ (Gonzales et al., 2010). Ca-O uptake bands on crab shell sample of decomposition at temperature $1000^{\circ} \mathrm{C}$ is seen on $354,9 \mathrm{~cm}^{-1}$ area. The results of the analysis before decomposition also have peaks in the same area but the intensity increases after the decomposition process. The band was reinforced by the appearance of peaks on the wavelength regions $871,82 \mathrm{~cm}^{-1}$, and $956.69 \mathrm{~cm}^{-1}$. Figure $4 \mathrm{~B}$ also shows the vibration of $1049.28 \mathrm{~cm}^{-}$ 1 which predicted the vibration region for $\mathrm{C}-\mathrm{O}$. The $\mathrm{O}-\mathrm{C}-\mathrm{O}$ 
stretching bond of carbonate appears at the peak at 1635,64 cm${ }^{1}$ wave numbers.

In Figure $4 \mathrm{~A}$ there was a peak in the vibration region of $3448,72 \mathrm{~cm}^{-1}$ predicted to be the region for $\mathrm{O}-\mathrm{H}$, this was reinforced in the spectrum after the decomposition at $1000^{\circ} \mathrm{C}$ resulting peak at $3641,6 \mathrm{~cm}^{-1}$ was the specific area for free $\mathrm{O}-\mathrm{H}$. The presence of the $\mathrm{OH}$ group indicated a peak matching of the sample vibrations analyzed by standard $\mathrm{CaO}$. The results of the analysis indicating the presence of $\mathrm{OH}$ groups of $\mathrm{Ca}(\mathrm{OH})_{2}$ identify the possibility of water adsorbed on the surface of $\mathrm{CaO}$, because $\mathrm{CaO}$ is very easy to absorb water vapor from the air (Grandos et al., 2007) .The data of the waveform of the preparation results shown by FT-IR Supports XRD diffraction pattern data. Further identification is done by using SEM-EDX.

\section{Identification of Calcium Oxide Results of Preliminary Shell Concrete by SEM-EDX Analysis}

The best shell decomposition was at $1000{ }^{\circ} \mathrm{C}$, and for undecomposed solids, calcum oxide analysis is performed by using SEM-EDX. From the analysis results can be seen dearly the difference between the two, as presented in Figures 5.

From Figure $5 \mathrm{~B}$ and $\mathrm{D}$ above the changes in the composition of crab shell before and after decomposition can be seen with EDX analysis. Prior to the decomposition process, the composition of shell crabs comprised of carbon $50.59 \%$, magnesium 5.10\%, $\mathrm{P}_{2} \mathrm{O}_{5} 3.41 \%, \mathrm{CaO} 34.57 \%$, $\mathrm{CuO} 3.68 \%$ and $\mathrm{ZnO} 2.65 \%$. After decomposition at $1000{ }^{\circ} \mathrm{C}$ there was a decrease for some carbon components to $29.57 \%$, $\mathrm{ZnO} 2.19 \%$. But there was an increase in $\mathrm{CaO}$, magnesium, $\mathrm{P}_{2} \mathrm{O}_{5}$ and $\mathrm{CuO}$ to $49.71 \%, 6.39 \%$ and $8.39 \%$, and $3.75 \%$. This is because after the decomposition process with a high enough temperature, the compounds are decomposed into expected target compounds.

\section{Synthesis of Biodiesel by Transesterification of WCO, Palm Oil and Coconut with Calcium Oxide Catalyst Decomposition Result from Shell of Combination at Temperature $1000^{\circ} \mathrm{C}$}

Calcium oxide resulting from decomposition process of crab shell at decomposition temperature of $1000{ }^{\circ} \mathrm{C}$ which has been characterized furthermore used as base catalyst in biodiesel synthesis through transesterification reaction of cooking oil, palm oil and coconut oil. The biodiesel product obtained from the transesterification reaction is in the upper layer, the top layer is removed and distilled. Pure biodiesel produced as much as $40.71 \%$ of cooking oil, $58.57 \%$ of palm oil, and $67.85 \%$ of coconut oil. The biodiesel is then characterized by determination of density, viscosity, acid number and iodine number.

Characterization of Biodiesel by Transesterification of WCO with Calcium Oxide Catalyst Decomposition Result of the Crab Shell at Temperature $1000{ }^{\circ} \mathrm{C}$

The results of analysis on biodiesel by determination of density, viscosity, acid number and iodine number are presented in Table 2.

\section{Biodiesel Product Weight Test (ASTM D-1298)}

Density provides information on how the fuel will work in a diesel engine. According to SNI 04-7182-2006 density of diesel fuel specifications should be in the range 0.82 to $0.900 \mathrm{~g} / \mathrm{cm}^{3}$. Tests were performed on biodiesel products, with an average value obtained for cooking oil of $0.8621 \mathrm{~g} / \mathrm{cm}^{3}$, for palm oil
$0.8725 \mathrm{~g} / \mathrm{cm}^{3}$, and for coconut oil of $0.8688 \mathrm{~g} / \mathrm{cm}^{3}$. Density for each oil prior to transesterification reaction yields $0.8900 \mathrm{~g} / \mathrm{cm}^{3}$ of cooking oil, palm oil $0.8731 \mathrm{~g} / \mathrm{cm}^{3}$, and coconut oil 0.8818 $\mathrm{g} / \mathrm{cm}^{3}$. The density values of biodiesel products obtained are induded in the standard range of biodiesel from SNI.

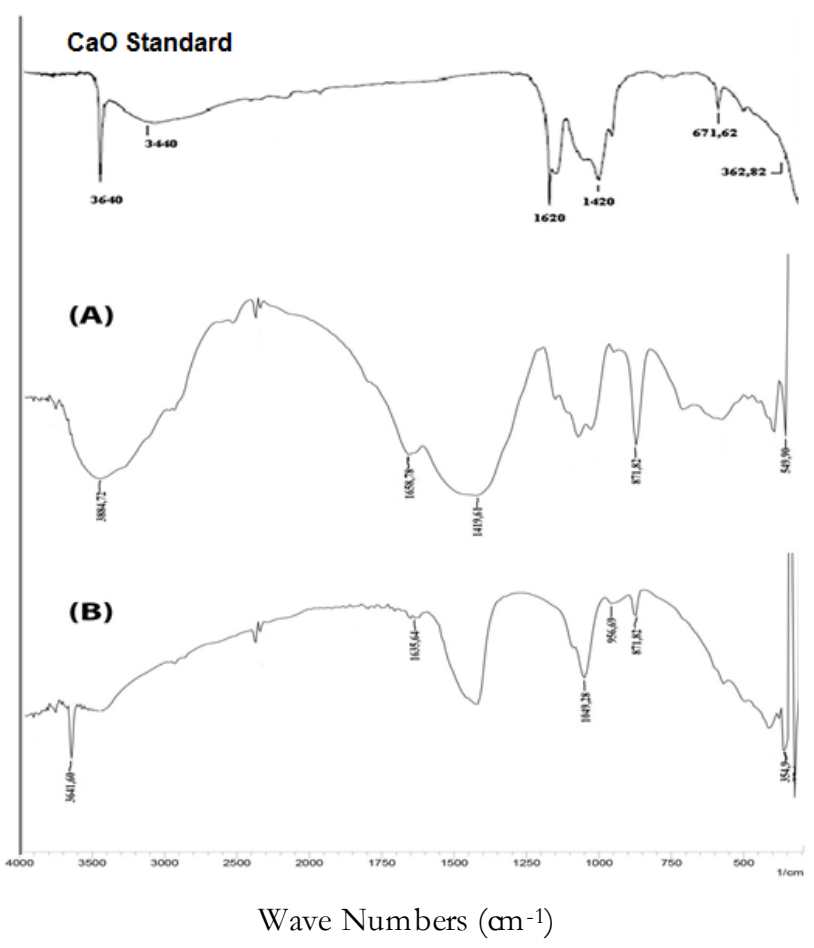

Figure 4. FTIR spectrum of crab shell (A) and decomposition result at $1000^{\circ} \mathrm{C}(\mathrm{B})$.

\section{Viscosity Value of Biodiesel Products (ASTM D-445)}

Viscosity is defined as fluid resistance to the flow rate of an mm-sized capillary (Sartika, 2009). Viscosity for each oil as initial measurement before transesterification of cooking oil, palm oil and palm oil respectively $48.2516 \mathrm{~mm}^{2} / \mathrm{s}(\mathrm{cst}), 34.0600$ $\mathrm{mm}^{2} / \mathrm{s}(\mathrm{cst})$ and $21.6150 \mathrm{~mm}^{2} / \mathrm{s}(\mathrm{cst})$. The result of viscosity measurement on biodiesel product of synthetic from WNT is $5.27 \mathrm{~mm}^{2} / \mathrm{s}(\mathrm{cst})$, palm oil $3.71 \mathrm{~mm}^{2} / \mathrm{s}(\mathrm{cst})$, and coconut oil 2.45 $\mathrm{mm}^{2} / \mathrm{s}(\mathrm{cst})$. Based on the standard value for biodiesel at SNI 04$7182-2006$, the standard biodiesel standard viscosity value is 2.3$6.0 \mathrm{~mm}^{2} / \mathrm{s}$ (cst). Based on the characterization data obtained from the use of the calcium oxide catalyst from the crab shell of the decomposition at a temperature of $1000{ }^{\circ} \mathrm{C}$ yields a viscosity value for biodiesel in accordance with SNI assumed standard.

\section{Acid Numbers}

The result of acid number determination on biodiesel product with titration method got average value from repetition three times equal to $0.3069 \mathrm{mg} / \mathrm{KOH}$ for cooking oil, 0.2423 $\mathrm{mg} / \mathrm{KOH}$ for palm oil and $0.2100 \mathrm{mg} / \mathrm{KOH}$ for oil coconut. With preliminary measurement results for each oil of 6.8666 $\mathrm{mg} / \mathrm{KOH}$ for cooking oil, $5.6144 \mathrm{mg} / \mathrm{KOH}$ of palm oil, and $2.6254 \mathrm{mg} / \mathrm{KOH}$ of coconut oil. As the ratio of the adid value of each oil according to SNI Standard the maximum of 0.8 $\mathrm{mg} / \mathrm{KOH}$. From the data it can be conduded that the biodiesel product produced has the value of acid number in accordance with SNI 04-7182-2006 standard. 


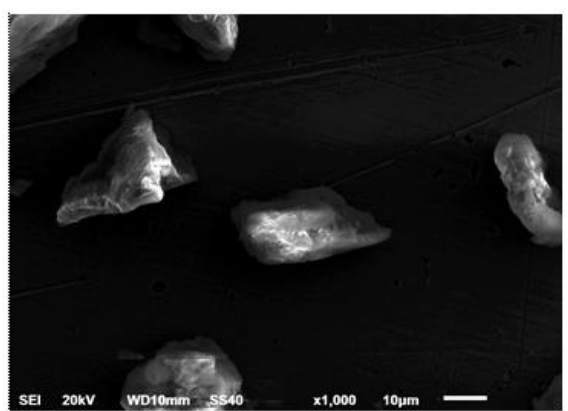

(A)

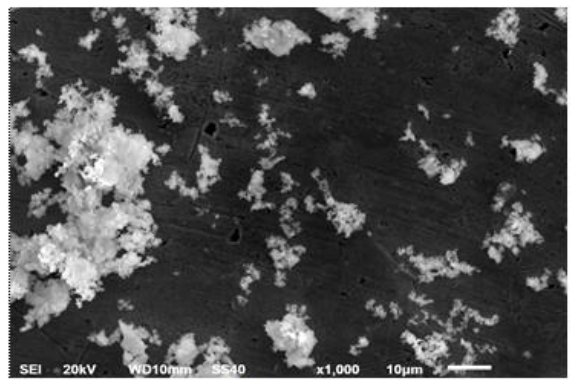

(C)

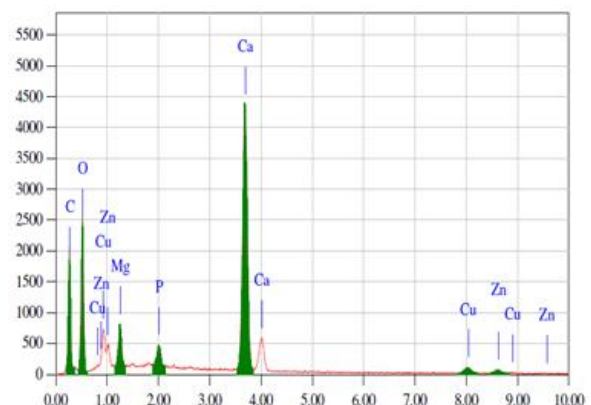

(B)

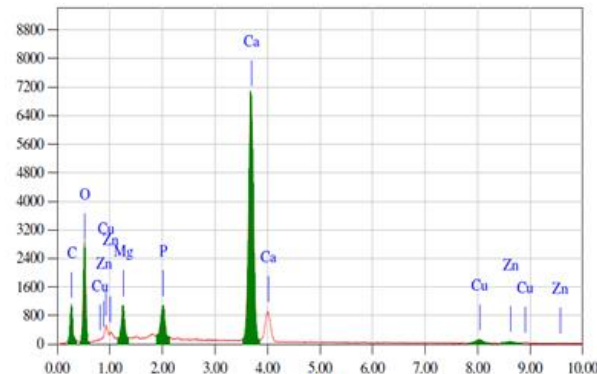

(D)

Figure 5. SEM and EDX Analysis Results of Crab Shells (A), (B) and after it was decomposed at $1000^{\circ} \mathrm{C}$ (C), (D).

Table 2. Data of biodiesel characterization result of synthetic from cooking oil, palm oil and coconut oil and biodiesel standard based on SNI 04-7182-2006.

\begin{tabular}{|c|c|c|c|c|c|c|c|c|}
\hline & \multicolumn{4}{|c|}{ Initial Oil Sample } & \multicolumn{4}{|c|}{ Biodiesel product sample } \\
\hline $\begin{array}{l}\text { Oil } \\
\text { Sample }\end{array}$ & $\begin{array}{l}\text { Density } \\
\left(\mathrm{g} \mathrm{cm}^{-1}\right)\end{array}$ & $\begin{array}{l}\text { Viscosity } \\
\left(\mathrm{mm}^{2} / \mathrm{s}\right)\end{array}$ & $\begin{array}{l}\text { Acid } \\
\text { Number } \\
(\mathrm{mg} / \mathrm{KOH})\end{array}$ & $\begin{array}{l}\text { IOD } \\
\text { Number } \\
\left(\mathrm{gI}_{2} / 100 \mathrm{~g}\right)\end{array}$ & $\begin{array}{l}\text { Density } \\
\left(\mathrm{g} \mathrm{cm}^{-1}\right)\end{array}$ & $\begin{array}{l}\text { Viscosity } \\
\left(\mathrm{mm}^{2} / \mathrm{s}\right)\end{array}$ & $\begin{array}{l}\text { Acid } \\
\text { Number } \\
(\mathrm{mg} / \mathrm{KOH})\end{array}$ & $\begin{array}{l}\text { IOD } \\
\text { Number } \\
\left(\mathrm{gI}_{2} / 100 \mathrm{~g}\right)\end{array}$ \\
\hline $\begin{array}{l}\text { Jelantah } \\
\text { Oil }\end{array}$ & 0.8900 & 48.2516 & 6.8666 & 51.66 & 0.8621 & 5.27 & 0.3069 & 39.48 \\
\hline Palm oil & 0.8731 & 34.0600 & 5.6144 & 45.92 & 0.8725 & 3.71 & 0.2423 & 36.12 \\
\hline $\begin{array}{l}\text { Coconut } \\
\text { Oil }\end{array}$ & 0.8818 & 21.6150 & 2.6254 & 36.54 & 0.8688 & 2.49 & 0.2100 & 9.24 \\
\hline $\begin{array}{l}\text { Biodiesel } \\
\text { Standard }\end{array}$ & - & - & - & - & $\begin{array}{l}0.85- \\
0.89\end{array}$ & $0.2-6.0$ & Max 0.8 & Max 115 \\
\hline
\end{tabular}

\section{Biodiesel Product Iod Value (AOCS Cd 1-25)}

The result of determination of number of Iod from biodiesel product got average value from repetition 3 times equal to 39,48 $\mathrm{g} \mathrm{I}_{2} / 100 \mathrm{~g}$ for cooking oil, $36.12 \mathrm{~g} \mathrm{I}_{2} / 100 \mathrm{~g}$ for palm oil, and 9.24 $\mathrm{g} \mathrm{I}_{2} / 100 \mathrm{~g}$ for oil coconut. The results of the analysis show that the iodine number of each biodiesel produced by synthesis is in accordance with the standard value of biodiesel set by SNI. Biodiesel with high iodine content exceeding the standard biodiesel quality standard $115 \mathrm{~g} \mathrm{I}_{2} / 100 \mathrm{~g}$ will result in polymerization tendency and deposit formation in noozle injectors and piston rings at the time of decomposition (Soerawidjaja, 2006). The iodine number of each oil prior to transesterification was $51.66 \mathrm{~g} \mathrm{I}_{2} / 100 \mathrm{~g}$ of cooking oil, $45.92 \mathrm{~g}$ $\mathrm{I}_{2} / 100 \mathrm{~g}$ of palm oil and $36.54 \mathrm{~g} \mathrm{I}_{2} / 100 \mathrm{~g}$ of coconut oil.

\section{CONCLUSION}

The best decomposition temperature of crab shell at 1000 ${ }^{\circ} \mathrm{C}$. The results of XRD characterization, FT-IR decomposition of shrimp shells show the presence of $\mathrm{CaO}$, and SEM-EDX analysis shows differences in homogeneity of crab surface shell before and after decomposition. The quality of biodiesel produced from cooking oil, palm oil, and coconut oil meets the SNI standard with density $\left(0.8621-0.8725 \mathrm{~g} / \mathrm{cm}^{3}\right)$, viscosity (2.45-5.27 m m²/s(cst), Acid number (0.1944-0.2842 mg/KOH), and iodine number (9.24-39.48 $\left.\mathrm{gI}_{2} / 100 \mathrm{~g}\right)$. Biodiesel products from cooking oil, palm oil and coconut oil yield percent yield of $40.71 \%, 58.57 \%$, and $67.85 \%(\% \mathrm{v} / \mathrm{v})$.

\section{REFERENCES}

Agrawal, S., Singh B., Sharma.Y.C. 2011. Exoskeleton of Mollusk (Pila Globosa) as a Heteregeneous Catalyst for Synthesis of Biodisel Using Fring Oil. Industrial \& Engineering Chemistry Research.Vol 51, 37:11875-11880.

Amriana, Dessy. 2014. Preparasi Kalsium Oksida dari Cangkang Telur Bebek (Anas Moscha) Untuk Produksi Biodiesel dari Minyak Jelantah. Skripsi Mahasiswa Kimia FMIPA, Universeitas Sriwijaya 
Boey, Peng-Lim., Gaanty, P.M., \& Shafida, A.H.2009. Biodiesel production via transesterifikasi of palm olein using waste mud crab (Scylla serrata)shell as a heterogeneous catalyst.Bioresource Technology, Vol100: 632-6368.

Ceria, S.O. 2013. Preparasi Kalsium Oksida Dari Tulang Sapi Dan Tulang Ikan Sebagai Katalis Heterogen Untuk Sintesis Biodiesel Dari Minyak Jelantah. Skripsi Mahasiswa Kimia. Universitas Sriwijaya

Gonzales, M., Hennandes, E., Ascencio, J.A., Pacheco, F., \& Pacheco, S.2010. Hidroksiapatite Cristal Grown on A Selulosa Matrix Using Titanium Alkokxide As a coupling agen. Jurnal of Material Chemistry. Vol.13: 2948-2951

Granados, M. L., Alonso, D. M., Sadaba, I., and Ocon, P. 2009. Leaching and Homogeneous Contribution in Liquid Phase Reaction Catalysed by Solids : The Case of Triglycerides methanolysis using CaO. Appl. Catal. B-Environ., 89 (1-2), 265-272.

Lesbani, A., Palita, T., Risfidian, M., Fahmariyanti . 2013. Preparation of Calcium Oxide from Achatina Fulica As Catalyst for Production of Biodiesel from Waste Cooking Oil. Indo. J. Chem, 13 (2), $176-180$.
Ma, F., and Hanna, M. A. 1999. Biodiesel Production ; A. Review. Bioresource Technology, Vol. 70: 1-115.

Nakatani, N., Takamori, H., Takeda, K., \& Sukugawa, H. 2009. Transesterification of Soyben Oil Using Combusted Oyster Shell Waste as a Catalyst. Bioresourse Technology, Vol.100:15101513.

Sartika, D.2009. Penentuan Persen Volume Fraksi Minyak Mentab (Crude Petroleum) dengan Metode Distilasi secara ASTM D-86 di PT.Pertamina EP Region Sumatera Field Pangkalan Susu. Kimia FMIPA USU. Medan.

Soerawidjaja, T.H. 2006. Minyak Lemak dan Produk-Produk Kimia Lain Dari Kelapa. Program Studi Teknik Kimia. Bandung.

Sueb, Abi. 2014. Aplikasi Kalsium Oksida Hasil Preparasi dari Cangkang Telur Puyuh Sebagai Katalis dalam Sintesis Biodiesel dari Minyak Jelantah. Skripsi Mahasiswa Kimia FMIPA, Universitas Sriwijaya

Tamba, P. 2012. Studi Preparasi Katalis Oksida Logam dari Cangkang Bekicot (AchatinaFulica) dan Aplikasinya dalam Sintesis Biodiesel dari Minyak Jelantah. Skripsi Mahasiswa Kimia FMIPA, Universitas Sriwijaya. 